\title{
Sandra Gregson
}

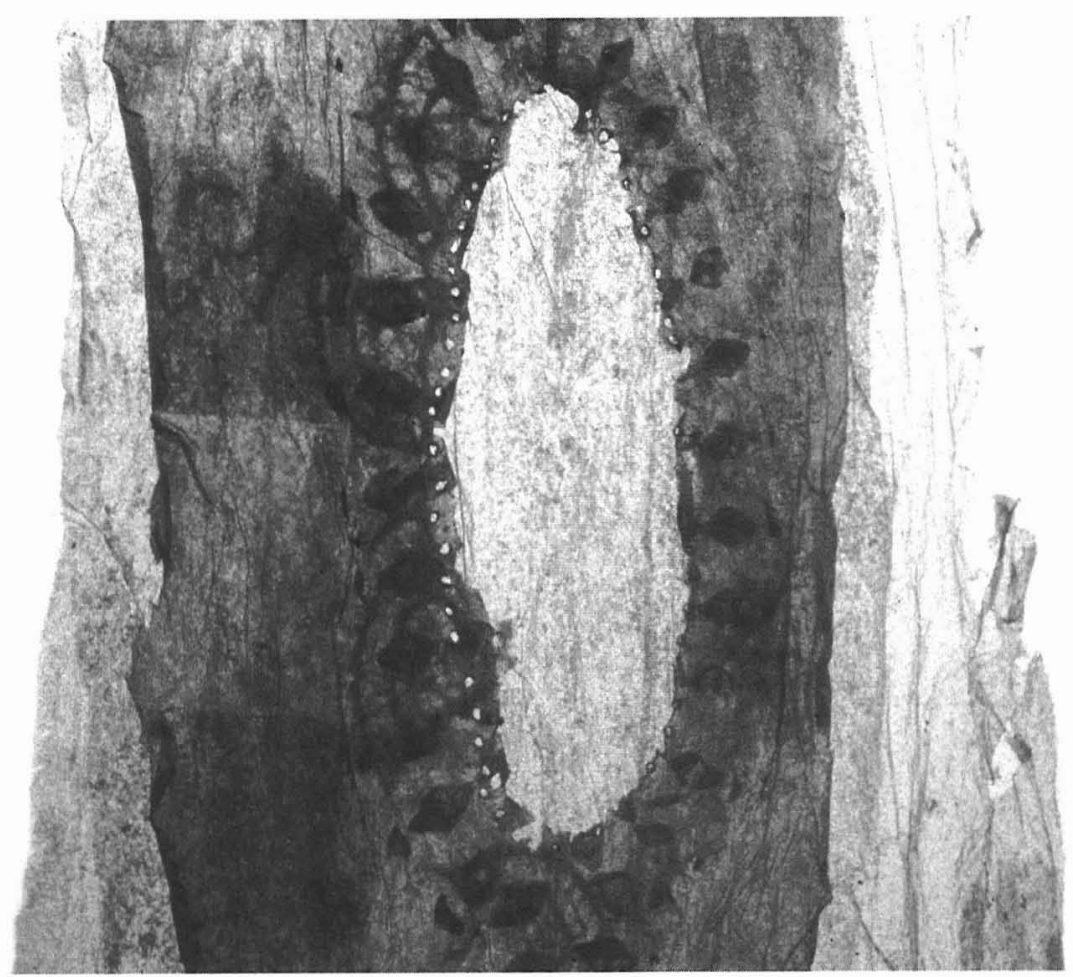

detail, Mind of Flesh (instilled), 1997, tissue paper, Japanese tissue, rabbit skin glue, flax string, $129 \times 85.6 \mathrm{~cm}$, photo: Simon Glass 
$62 \cdot$ Tessera

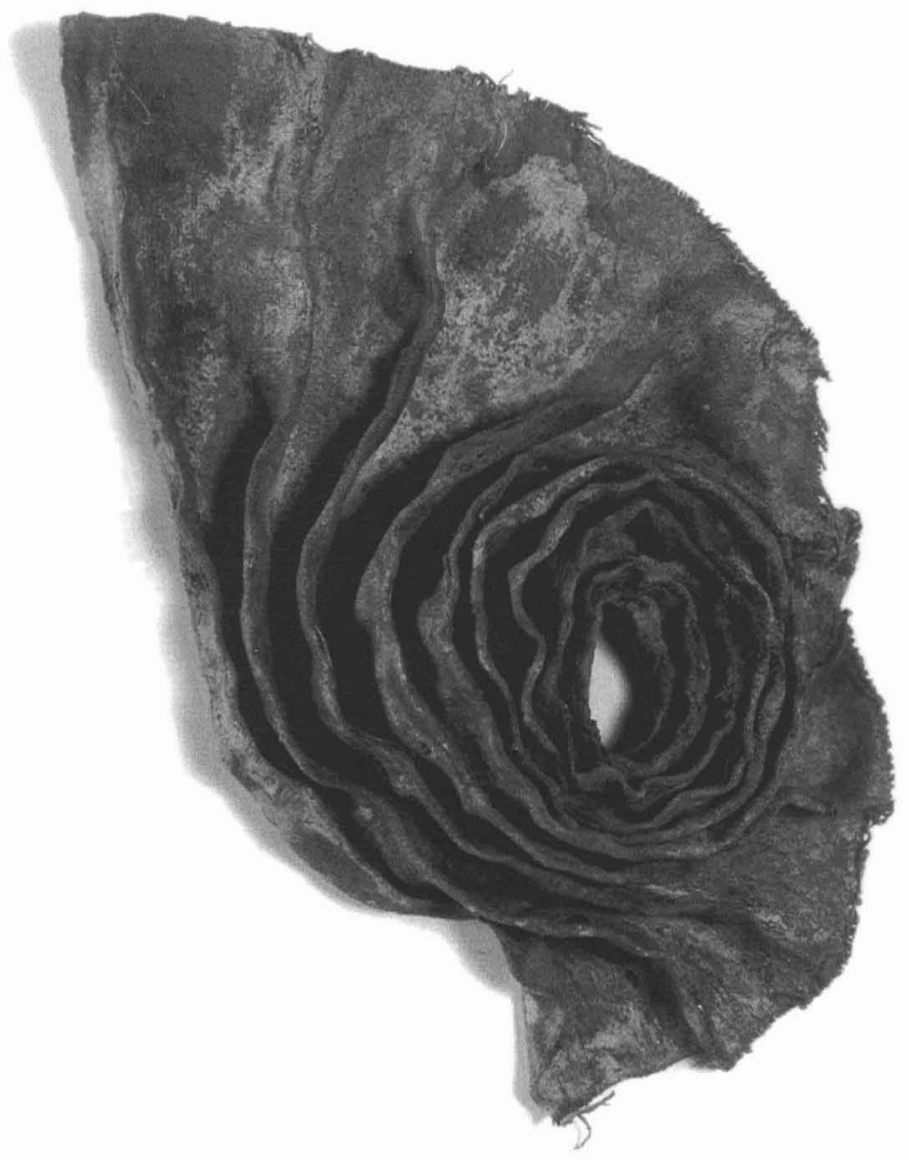

Swaddling, 1992, cement fondue, burlap, copper wire, 59 x 47 x 11cm, photo: Simon Glass 


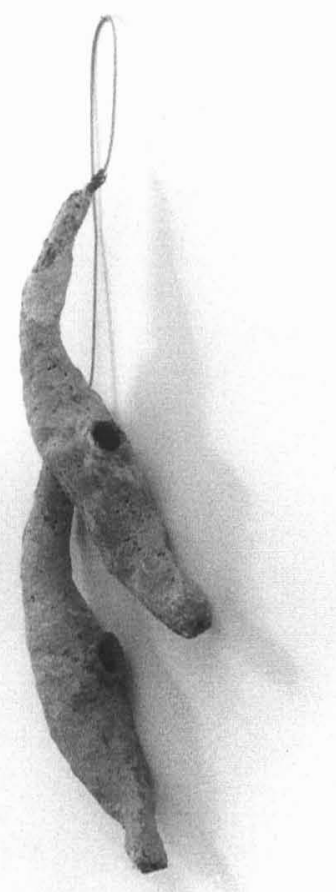

Freudian Slippers, 1991, cable, cement, cement fondue, fibreglass cloth, wire mesh, $106 \times 38 \times 13 \mathrm{~cm}$, photo: Simon Glass 


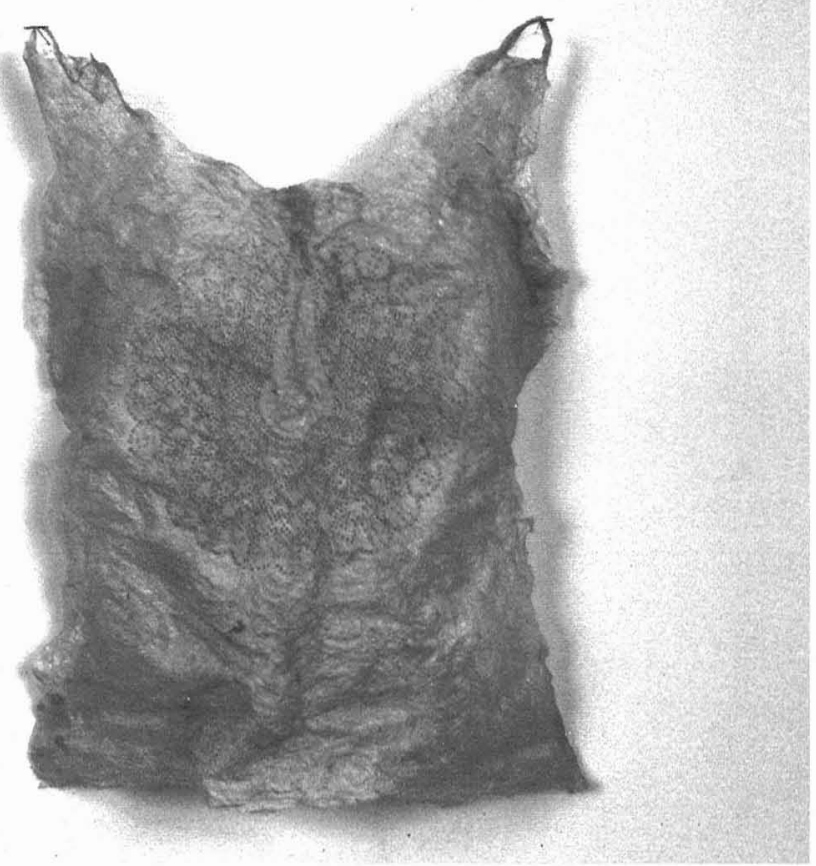

(untitled), 1997, silk tissue, rabbit skin glue, photocopy, heat transfer, $43 \times 30 \times 11 \mathrm{~cm}$, photo: Simon Glass 